\title{
PERLINDUNGAN DAN PENGELOLAAN KEANEKARAGAMAN HAYATI INDONESIA OLEH PEMERINTAH DAN MASYARAKAT
}

\author{
PROTECTION AND MANAGEMENT OF INDONESIA'S BIODIVERSITY BY \\ GOVERNMENT AND SOCIETY
}

\author{
Christin S. Basani*
}

\begin{abstract}
ABSTRAK
$\mathrm{P}$ engelolaan dan perlindungan kawasan hutan yang merupakan salah satu keanekaragaman hayati harus terus diperhatikan. Kesadaran masyarakat harus terus menerus ditumbuhkan didaerah yang masyarakatnya mengandalkan mata pencahariannya dari alam berupa pertanian, perikanan maupun dari hutan. Pengelolaan dan perlindungan keanekaragaman hayati membutuhkan peran pemerintah sebagai regulator kebijakan yang erat berhubungan dengan kesejahteraan rakyat. Istilah "tebang butuh' tidak akan muncul lagi bila pemerintah membantu masyarakat dengan prinsip partisipasi, transparansi, efisiensi, akuntabilitas dan keadilan. Sehingga keberlanjutan sumber daya alam bagi lingkungan sekitarnya akan terus ada dan membentuk ekosistem lingkungan yang memberikan manfaat. Kearifan lokal pada hutan yang dimiliki masing-masing daerah menjadi nilai tersendiri yang diatur dalam Undang-Undang Lingkungan Hidup No. 32 Tahun 2009. Kearifan lokal akan terus dijaga dan dilestarikan sebagai penopang kehidupan masyarakat lokal. Masyarakat tidak akan bisa bekerja sendiri tanpa bantuan dari pemerintah.

Salah satu contoh kearifan lokal yaitu pohon jati yang tumbuh dilahan yang terletak di Girisekar, Kecamatan Panggang, Gunungkidul, Yogyakarta. Pohon jati tersebut mampu menyelamatkan masa depan anak dari pemilik pohon jati. Untuk membiayai sekolah anaknya, pemilik menebang enam pohon dengan harga jual 25 juta. Selain itu ada kerumunan pohon jati yang akan terus tumbuh sebagai masa depan penduduk di kampung Girisekar Kecamatan Panggang Gunungkidul. Pohon jati tersebut sebagai tumbuhan berkayu yang muncul di tanah milik perorangan yang kerap disebut hutan rakyat atau hutan hak. Penebangan dengan sistem "tebang butuh" menjadi solusi bagi warga masyarakat, disamping itu ada keinginan dari warga masyarakat untuk bisa melestarikan hutan sebagai bagian dari kehidupan masyarakat di sana.

Metode penelitian yang digunakan dalam penelitian ini yuridis normatif, dengan melihat peraturan perundangan, diantaranya UU Lingkungan Hidup No. 32 tahun 2009. Melihat permasalahan kearifan lokal dan perlindungan terhadap keanekaragaman hayati dan pengelolaannya untuk kemanfaatan bagi warga atau masyarakat sekitar yang menjadi bagian dari kehidupan bersama.
\end{abstract}

Kata kunci: keanekaragaman hayati; pengelolaan dan perlindungan; kearifan lokal.

\footnotetext{
* Universitas Kristen Maranatha Bandung, Jl. Prof. drg. Surya Sumantri, M.P.H No 65 Bandung 40164, email: christinseptina@yahoo.co.id.
} 


\begin{abstract}
$T$ leak trees that grow in dilis located in Girisekar, Panggang District, Gunungkidul, Yogyakarta by one of its owner named Andreas Sihono able to save the future of his son. To finance his son's school, Sihono cuts down six trees at a selling price of 25 million. In addition there is a crowd of teak trees that will continue to grow as the future of residents dikampung Girisekar Panggang Gunungkidul District. The teak tree as a woody plant that emerged on the land belonging to individuals who often called the community forest or forest.
\end{abstract}

How to grow woody plants (which are not only teak but there are mahogany trees, acacias and some bamboo groves) are various. There are grown in rocky areas so as to disguise boulders, or grow/planted in intercropping (trees planted on the edge of the boundary of the land, while in the middle of a land that is thickly overgrown with seasonal crops such as cassava and maize). This people's forest is different from the previous years, where the people there do not maintain sustainable forest management. The "cuttingedge" system makes the Girisekar community able to cut down regardless of forest sustainability as a spring protection. The restriction of harvesting every year and pay attention to its management make the people's forest become the area that must be preserved, not only provide economic benefits mere. The research method used in this study is normative juridical, by looking at the laws and regulations, including Environmental Law No. 32 of 2009.

The management and protection of forest areas that are one of biodiversity must be kept in mind. Public awareness must be continuously grown in the areas where people rely on their livelihoods from nature in the form of agriculture, fisheries and forest. Management and protection of biodiversity requires the role of government as a policy regulator closely related to people's welfare. The term "cutting need" will not reappear if the government helps the community with the principles of participation, transparency, efficiency, accountability and fairness. So that the sustainability of natural resources for the surrounding environment will continue to exist and form a beneficial ecosystem environment. Local wisdom in the forests owned by each region becomes its own value as regulated in the Environmental Law No.32 of 2009. Local wisdom will be maintained and preserved as the support of local people. The community will not be able to work alone without government support.

Keywords: biodiversity; management and protection; local wisdom.

\section{PENDAHULUAN}

$\mathrm{T}^{\mathrm{s}}$ 2015 menjadi tahun dengan waktu terlama untuk kebakaran hutan dibeberapa wilayah Indonesia, khususnya wilayah Provinsi Riau, Jambi, Sumatera Selatan, Kalimantan Barat, Kalimantan Tengah dan Kalimantan Selatan dibandingkan tahuntahun sebelumnya. Sehingga diistilahkan untuk peristiwa yang terjadi dengan istilah 'Tragedi Kabut Asap 2015'. Kebakaran hutan yang terjadi sejak sekitar bulan Juli menyebar ke wilayah hutan-hutan gambut hingga akhir bulan Oktober sampai menunggu turunnya hujan yang menandai musim hujan dimulai. Tragedi ini menjadi tragedi asap terbesar sejak Indonesia merdeka selain kebakaran tahun 1997. Bedanya dengan tahun 1997, durasi kabut asap tahun ini jauh lebih panjang. Menurut data Badan Nasional Penanggulangan Bencana (BNPB) menyebutkan kebakaran lahan dan hutan di Indonesia tahun ini memberikan dampak terhadap 43 juta jiwa. Tahun 1997, data Badan Meteorologi, Klimatologi dan Geofisika (BMKG) menyebut, angka terdampak sekitar 20 juta jiwa. Kabut asap1997 juga muncul 
secara sporadis, tidak setiap hari seperti tahun 2015 ini. $^{1}$

Kebakaran hutan yang menyebabkan kabut asap pada tahun ini terjadi lebih dari tiga bulan dan skala dampak kebakaran lahan dan hutan tahun 2015 ini masuk dalam kategori bencana kemanusiaan. Sedangkan bencana pada tahun 1997 tidak sampai dua bulan serta tidak terjadi setiap hari. Di Jambi, pada tahun 1997 dari jarak pandang terendah sekitar 300 meter, kalau bencana tahun ini menurut BMKG Jambi yang mengukur jarak pandang terendah tahun ini hanya 50 meter. Dampaknya melumpuhkan aktivitas penerbangan hampir dua bulan dan mematisurikan ekonomi rakyat. Aktivitas pendidikan pun terhenti hampir sebulan.

Kebakaran hutan yang menimbulkan kabut asap terjadi di area-area hutan dan lahan yang berada di daerah Sumatera dan Kalimantan. Pembukaan lahan dengan cara membakar dirasa cukup efektif bagi orang yang melakukannya tanpa menyadari akibatnya. Akibat yang ditimbulkan bukan hanya terjadi dalam negeri tapi juga menjadi perhatian negara-negara tetangga seperti Malaysia, Singapura. Kebakaran yang terjadi dikawasan hutan yang bisa digunakan sebagai tanaman industri dan perkebunan. Hutan yang memiliki keanekaragaman hayati yang seharusnya ada pengelolaan dan perlindungan dari pemerintah. Selama hampir dua dasawarsa, kabut asap akibat pembakaran lahan menjadi persoalan rutin di negeri ini. Persoalan nasional yang tak kunjung terselesaikan.

Menjadi permasalahan dari pemaparan di atas adalah, pengelolaan lingkungan hidup khususnya dalam hal pengelolaan keanekaragaman hayati yang menjadi kekayaan bangsa Indonesia. Keanekaragaman hayati berupa hutan dengan segala potensinya bila dikelola dengan baik akan menjadi kekayaan tersendiri. Permasalahan muncul apabila keanekaragaman hayati tersebut berbeda untuk setiap daerahnya, sehingga kearifan lokal setiap daerah berbeda. Bagaimana peran pemerintah dan masyarakat terhadap pengelolaan keanekaragaman hayati dikaitkan dengan kearifan lokal setiap daerah khususnya keanekaragaman hayati hutan akan menjadi pembahasan dalam tulisan ini.

\section{METODE PENELITIAN}

$\mathrm{M}$ etode penelitian yang digunakan dalam penelitian ini menggunakan metode yuridis normatif dengan mendasarkan pada sumber data primer, sekunder dan tersier. Arti dari penelitian yuridis normatif yakni melakukan penelusuran terhadap norma-norma hukum yang terdapat dalam peraturan perundang-undangan yang berkaitan dengan Lingkungan Hidup yaitu Undang-undang Lingkungan Hidup No. 32 Tahun 2009, serta untuk memperoleh data maupun keterangan yang terdapat dalam berbagai literatur, perpustakaan, jurnal hasil penelitian, koran, majalah, situs internet dan sebagainya. ${ }^{2}$ Dalam penelitian ini penulis akan mencoba menggambarkan situasi dan kondisi pengelolaan keanekaragaman hayati yang dimiliki Indonesia melalui hutan sebagai kekayaan alam bangsa Indonesia melalui kearifan lokal masing-masing daerah dan peran dari pemerintah dan masyarakat kemudian dianalisis menggunakan bahan hukum primer, sekunder dan tersier.

Penelitian ini menggunakan pendekatan peraturan perundang-undangan dan pendekatan kasus. Pendekatan perundang-

\footnotetext{
${ }^{1}$ Harian Kompas, 26 Oktober 2015.

2 Sunaryati Hartono, Penelitian Hukum di Indonesia pada Akhir Abad Ke-20, Alumni, Bandung, 1994, hlm 139.
} 
undangan beranjak dari peraturan hukum berkenaan dengan lingkungan hidup khususnya pengelolaan keanekaragaman hayati dan peran pemerintah serta masyarakat. Sedangkan pendekatan kasus dengan melihat permasalahan di masyarakat yang terkait dengan pengelolaan keanekaragaman hayati. Dalam penelitian ini menggunakan jenis data yang bersumber dari bahan hukum primer; bahan hukum sekunder dan bahan hukum tersier.

\section{PEMBAHASAN}

$\mathrm{K}_{\mathrm{b}}^{\mathrm{e}}$ ebakaran lahan yang menimbulkan bencana kabut asap, tahun ini setidaknya menelan korban hingga kurang lebih 14 orang meninggal dunia. Keempat belas orang yang meninggal tersebar di beberapa provinsi, yakni di Riau, Jambi, Sumatera Selatan, Kalimantan Tengah serta Kalimantan Utara. Bila dibandingkan jumlah orang yang meninggal tahun 1997, data Kementerian Lingkungan Hidup dan Program Pembangunan PBB menyebut angka 527 orang selama SeptemberNovember 1997, tapi data itu dibantah oleh Kepala Pusat Data, Informasi dan Humas BNPB Sutopo Purwo Nugroho data tersebut tidak sebanyak itu.

Kebakaran yang terjadi tahun ini di wilayah Riau sudah menghanguskan sekitar 1.827 hektar lahan gambut. Sebarannya paling banyak di Kabupaten Palalawan, Indragiri Hilir, Kuantan Sengingi, Bengkalis, Kampar dan Siak. Satelit milik Badan Atmosfer dan Kelautan Nasional AS mendeteksi 1.239 titik panas di Riau, hampir setengah dari total sebaran titik panas di Sumatra dan Kalimantan. Ada beberapa upaya yang dilakukan untuk menanggulangi api, diantaranya Badan Nasional Penanggulangan

\footnotetext{
${ }^{3}$ National Geographic, September 2015.

${ }^{4}$ National Geographic, September 2015, hlm. 27.
}

Bencana (BNPB) menyewa helikopter berbom air buatan Rusia, MI-171 dan Sikorsky S61. Kantong berkapasitas 3.800 liter mengambil air dari Sungai kampar dan anak-anak Sungai Siak, lalu ditumpahkan ke lokasi-lokasi terbakar. Sejak akhir Juni, sudah lebih dari 1.100 pengeboman dilakukan dari ketinggian 50 hingga 100 meter. Biaya sewa heli untuk kegiatan ini menghabiskan Rp 80 juta per jam dengan durasi pemadaman biasanya berlangsung selama tiga jam. ${ }^{3}$

Upaya lain yang dilakukan adalah dengan menabur bubuk garam $(\mathrm{NaCl})$ ke awan kumulonimbus melalui operasi hujan buatan. Modifikasi ini sudah menghabiskan hampir 80 ton garam selama dua bulan terakhir. ${ }^{4}$ Badan Meteorologi, Klimatologi dan Geofisika (BMKG) telah mengingatkan perihal ancaman kekeringan akibat pengaruh dipole mode dan faktor el nino yang diprediksi berlangsung hingga akhir Agustus. Itulah yang menyebabkan kebakaran hutan terus berlanjut dan tiada henti. Selama masa itu, akan terjadi anomali suhu permukaan laut negatif yang menguat dan meluas di Khatulistiwa hingga pantai barat Sumatra. Sebanyak 17 kecamatan di Riau berada dalam kondisi sangat kering karena tidak mengalami hujan selama lebih dari sebulan bahkan sampai beberapa bulan.

Dengan pertimbangan di atas, pemerintah merasa perlu penanganan secara dini. BMKG Riau sudah memberi rekomendasi agar pemerintah melakukan modifikasi hujan pada akhir musim penghujan Juni lalu, karena masih banyak sebaran awan kumulonimbus. Namun yang terjadi justru pemerintah baru memodifikasi cuaca di akhir bulan, sedangkan Riau terlanjur memasuki kemarau. Karena tidak banyak lagi sebaran awan kumulonimbus sehingga hujan buatan menjadi tidak efektif. 
Ada cara mengatasi kebakaran lahan gambut dengan cara menyekat kanal-kanal gambut di seluruh wilayah perkebunan, agar permukaan lahan tetap basah. Tetapi sistem penyekatan kanal menurut pakar gambut dari Universitas Palangkaraya, Suwido Hester Limin dan Darmae Nasir, justru membuat gambut menjadi kering dan bisa mudah terbakar. Pembuatan kanal bersekat secara massal untuk mengatasi kebakaran hutan dan lahan di Sumatera dan Kalimantan menjadi sangat beresiko. Karena tujuan membuat lahan rawa gambut kembali basah malah berpotensi mengeringkan dan meningkatkan bahaya kebakaran di masa datang. Kanal yang dibuat langsung ke sungai menurunkan permukaan air tanah, dalam kondisi yang demikian akan membuat gambut menjadi kering dalam waktu yang relatif lama, tiga sampai lima bulan. Walau himbauan untuk melakukan kanalisasi dihimbau oleh Presiden Joko Widodo tapi proses ini tidak bisa mengatasi bahaya kebakaran yang terus menerus terjadi di setiap tahunnya.

Tahun 1997 dengan pemicu yang sama, yaitu el nino telah menghanguskan 11,6 hektar hutan Sumatra serta menyebarkan kabut asap hingga ke Singapura, Malaysia, dan Brunei. Kerugian Sumatra akibat kebakaran itu mencapai $\mathrm{Rp} 47$ trilliun. Sedangkan kerugian seluruh kawasan terdampak asap sebesar 760 juta dolar AS. ${ }^{5}$ Menurut data dari BNPB selama triwulan pertama tahun lalu, terdapat sebaran 12.541 titik panas di lahan gambut Sumatera yang juga mengakibatkan kerugian besar. Lebih dari 90 persen titik panas menyebar di wilayah Riau. Selama tiga pekan di puncak bencana bencana asap, dari akhir Februari hingga pertengahan Maret,
Riau sudah mengalami kerugian sebesar Rp 80 trilliun. Itu belum termasuk pengeluaran negara untuk pemadaman dari udara sebesar Rp 150 miliar. Ini baru satu provinsi saja yaitu Provinsi Riau, belum provinsi yang lain yang merupakan daerah kebakaran hutan dan lahan. Provinsi lain bisa mengalami kerugian yang tidak jauh beda yang diderita provinsi Riau, bisa dilihat kerugian negara secara tidak langsung terhadap bahaya kebakaran hutan dan lahan begitu besar dampaknya.

Dalam buku yang berjudul "Mengeksploitasi Keanekaragaman Hayati, Lingkungan dan Pandangan Masyarakat Lokal Mengenai Berbagai Lanskap Hutan“ yang ditulis oleh Douglas Sheil; Rajindra Kapuri dkk yang tergabung dalam proyek International Tropical Timber Organization (ITTO) menyebutkan kekhawatiran dunia terhadap hutan hujan tropis banyak bersumber pada kekhawatiran akan berbagai kepunahan besar yang akan terjadi. ${ }^{6}$ Sehingga berbagai upaya yang dilakukan sungguhsungguh difokuskan pada identifikasi lokasi yang memerlukan pengelolaan yang sensitif. Kegiatan survei dan penilaian dampak dihasilkan oleh lembaga-lembaga yang konsen dengan masalah lingkungan, tetapi penilaian tersebut hasilnya tidak berdampak bagi pihak-pihak yang berkepentingan, dalam hal ini pemerintah. Sehingga keputusan yang diambil pemerintah bukanlah keputusan yang berpihak pada masyarakat, terutama masyarakat lokal yang membutuhkan hutan sebagai keanekaragaman hayati selain harus dipelihara dan dilestarikan tapi bisa juga bermanfaat untuk kehidupannya sehari-hari sebagai sumber penghidupan.

${ }^{5}$ Ibid, hlm 28.

${ }^{6}$ Douglas Sheil, Rajindra Puri \& Tim ITTO; Pandangan Masyarakat Lokal Mengenai Berbagai Berbagai Lanskap Hutan; Center for International Forest Research, Jakarta, 2004; hlm. 12. 
Akibat pada kesehatan

Seperti ketika tahun lalu kebakaran yang Smenimpa Riau, membuat Kota Pekanbaru bagai hilang ditelan kabut asap. Tahun ini pun keadaannya tidak jauh berbeda, justru mungkin lebih parah. Penerbangan komersial pada waktu itu tidak beroperasi selama hampir dua pekan. Jalur distribusi barang, baik melalui laut dan udara menjadi terganggu. Pertanian mengalami gagal panen. Ratusan sekolah diliburkan. Ribuan warga mengungsi. Lebih dari 53.000 warga Riau menderita infeksi saluran pernafasan akut (ISPA), radang paru-paru, dan iritasi mata dan kulit. ${ }^{7}$ Kondisi ini tidak jauh beda dengan kondisi akibat kebakaran di tahun ini. Jalur penerbangan untuk daerah-daerah kebakaran ditutup, sekolah menjadi diliburkan untuk beberapa waktu serta korban jiwa berjumlah 14 orang akibat kebakaran yang menyebabkan kematian karena ISPA.

Bahaya yang disebabkan oleh asap bagi tubuh manusia ketika menghirupnya secara terus menerus sangatlah fatal. Sumber polutan berupa karbon monoksida yang tidak berwarna, tidak berbau, yang dihasilkan dari pembakaran kayu yang tidak sempurna, akan berikatan dengan hemoglobin dan menghasilkan karboksi hemoglobin. Dampaknya akan mengurangi transportasi oksigen ke organ vital. Hal ini seperti diungkapkan Spesialis Paru dari Rumah sakit Umum Daerah Arifin Achmad, dr Azizman Saad, mengatakan paparan kabut asap kebakaran lahan mengancam masa depan warga, bahkan polusi yang ditimbulkan dapat mematikan bayi dalam kandungan. Karena kadar oksigen semestinya mencapai 20 persen, saat terjadi pembakaran lahan, kadarnya menurun drastis hingga hanya 1 persen. Kondisi ini mengganggu asupan oksigen pada ibu hamil, sehingga berpotensi mengalami anemia fisiologis. Sang bayi akan terancam lahir dengan berat badan rendah atau bahkan mengalami kematian. Bayi yang lahir selamat pun tetap dapat mengalami masalah sel otak. Partikel debu atau partikulat yang terbangun di udara masuk ke tubuh manusia melalui pernafasan. Polutan ini dapat terisap sehingga efeknya menimbulkan risiko kerusakan paru. Partikulat juga mengiritasi bronkus, menyebabkan radang dan meningkatkan reaktivitas. Efeknya sangat potensial menyebabkan asama, ISPA, bronchitis kronis dan penyakit paru. Polutan lain yang berbahaya adalah kondensat asap biomassa. Karena jika masuk ke mata dan terabsorbsi lensa alami pada mata, polutan ini akan menimbulkan perubahan oksidatif yang mengakibatkan katarak.

\section{Akar Permasalahan pada Pengelolaan Hutan}

Cara mengatasi kondisi yang berlangsung seperti ini untuk setiap tahunnya yang berulang, adalah dengan menyetop pembakaran hutan dan lahan. Menurut seorang pakar gambut yang juga Direktur Pusat Syudi Bencana Universitas Riau, Haris Gunawan, mengatakan bahwa bencana ini bukan hanya persoalan praktik pembakaran lahan semata, tapi pada masalah salah kelola sumber daya alam. Karena eksploitasi besarbesaran kawasan gambut Riau sejak 1997 membuat masalah kebakaran hutan dan lahan tidak kunjung habis. Riau merupakan provinsi yang memiliki wilayah gambut terbesar di Sumatera. Luas areal gambutnya 5,7 juta hektare atau 60 kali luas Jakarta. Luas lahan gambut di Riau bahkan lebih dari setengah luas lahan gambut seluruh Sumatera yang mencapai 7,2 hektare, sebagai penyerap 18 juta ton karbon. 
Sebagian luas rawa gambut Riau mempunyai keunikan yaitu berkedalaman lebih dari tiga meter. Keputusan Presiden Nomor 32 Tahun 1990 tentang Pengelolaan Kawasan Lindung menyebutkan bahwa ada larangan mengalihfungsikan gambut berkedalaman lebih dari tiga meter. Tetapi aturan ini dilanggar secara leluasa, maka terjadilah pembukaan lahan secara masif dengan cara pembakaran di lahan gambut yang salah satunya digunakan untuk perkebunan sawit.

Pelanggaran atas Kepres No. 32 Tahun 1990 dimulai dari penebangan besar-besaran yang terjadi dalam skema Izin Hak Penguasaan Hutan (HPH) di masa Orde Baru, berlanjut dengan alih fungsi hutan gambut untuk kepentingan industri perkayuan. Pemberian Izin Konsesi Hutan Tanaman Industri (HTI) skala besar dan kecil yang kemudian meledak di era reformasi. Bahwa sebagian izin bisa dikata ilegal, karena melangkahi proses konversi hutan yang semestinya. ${ }^{8}$ Pembukaan hutan untuk perkebunan skala kecil pun belakangan marak terjadi. Asalkan bermodal besar, siapa pun bisa membuka kebun dengan hanya mengantongi surat keterangan jual beli lahan dari perangkat desa dan daerah. Sejak tahun 1997 luas hutan gambut Sumatera yang beralih menjadi konsesi HTI mencapai 4,5 juta hektare. Provinsi Riau memiliki konsesi HTI terluas dengan total hampir 2,1 juta hektar, sehingga menjadi provinsi yang paling luas kehilangan hutan alam, diikuti Sumatera Selatan dengan 1,3 juta hektare dan Jambi dengan luas lahan 663 hektare.

Permasalahan tidak hanya pada pemberian izin konsesi HTI tapi pembukaan kebun sawit juga menjadi persoalan yang tidak kalah gencarnya, karena pembukaan lahan terjadi begitu masifnya. Dalam dokumen rencana induk Kementerian
Lingkungan Hidup 2010, wilayah budi daya areal gambut sudah 4 juta hektar, menyisakan hanya 1,7 juta hektar sebagai kawasan lindung kubah gambut. Setelah penggundulan hutan, perusakan berikutnya adalah pembangunan saluran air atau kanal besar-besaran untuk tanaman industri dan sawit. Menurut Haris Gunawan, pakar gambut dari Universitas Riau, pembangunan jaringan kanal korporasi mau pun perorangan di Riau mencapai 13.510 unit, panjangnya mencapai 28 juta meter. Jika direntangkan, jarak itu setara dengan perjalanan bolak-balik Jakarta Los Angeles. Jaringan kanal yang ada telah merusak struktur hidrologis yang telah terbentuk dalam proses akumulatif pembusukan sisa tumbuhan selama ribuan tahun.

Sebagai penyimpan karbon, pengatur iklim, dan pelindung keragaman hayati, gambut terbentuk dari timbunan sisa-sisa tanaman mati. Pembentukan kubah gambut dimulai dari adanya cekungan permukaan yang secara perlahan ditumbuhi tanaman air dan vegetasi lahan basah. Sisa tanaman ini melapuk secara bertahap membentuk lapisan transisi antara gambut dan substratum atau lapisan di bawahnya, berupa tanah mineral. Cadangan air yang ada selama ini tersimpan dalam lapisan-lapisan tanah yang terbentuk dan membentuk kubah gambut yang permukaannya cembung. Efeknya dengan membuka kanal, cadangan air dalam gambut akan tersedot. Kelebihan air yang tertampung di kanal akan langsung terbuang ke laut. Gambut akan menjadi kering di musim kemarau, sehingga mudah terbakar karena mengandung bahan-bahan organik. Dalam kondisi kering, gambut akan mudah tersulut oleh api, ketika sudah tersulut oleh api, kebakarannya akan cepat meluas dan bertahan di balik permukaan. Berbeda dengan kebakaran biasa, kebakaran

8 Ibid, hal 29. 
pada lahan gambut sulit diduga, api yang tumbuh dari semak, serasah dan belukar menyebar tak menentu di bawah permukaan, membakar bahan organik melalui pori-pori gambut dan melalui akar semak belukar yang bagian atasnya terbakar. Api terus menjalar dengan membentuk kantong asap, sehingga pembakarannya tidak menyalanyala. Cenderung hanya tampak asap berwarna putih di atas permukaan, namun karena pemadamannya meluas di dalam lahan gambut sehingga pemadamannya menjadi sulit dipadamkan. Itulah sebabnya untuk pemadaman di lahan gambut menjadi sulit teratasi walau hanya dengan upaya penyemprotan atau pun dengan cara pengeboman air. Cara-cara seperti ini tidak akan mematikan api sampai ke dasarnya atau lapisan bawah, kecuali ada hujan yang turun terus-menerus selama berhari-hari, akan mematikan titik api sampai ke dasarnya.

Sulitnya pemadaman api di lahan gambut menjadi celah yang dimanfaatkan para pemodal dalam mengelola konsesi dan perkebunan sawit karena pembakaran menjadi sarana yang sangat efektif dan menghemat biaya produksi. Pembersihan lahan dengan cara membakar hanya menghabiskan Rp 1 juta hingga Rp 1,5 juta per hektare. Bila dibandingkan dengan cara tanpa membakar, dibutuhkan biaya hingga enam kali lipatnya. Hal ini (pembakaran hutan dan lahan) dirasa keadaan yang menguntungkan bagi pihak pemodal pengelola konsesi dan perkebunan sawit. Sehingga ada beberapa dugaan ditemukannya unsur kesengajaan dengan berbagai modus operandi pada sebagian besar peristiwa kebakaran di wilayah korporasi. Selain untuk menghemat biaya dan memperoleh pemupukan dari hasil abu bakaran kayu mineral, pemilik lahan meraup keuntungan berkali lipat dengan memanipulasi pinjaman sindikasi bank. Bahkan ada pula yang untuk memperoleh klaim asuransi yang bernilai miliaran rupiah, atau membiarkan lahan terbakar sehingga terkesan lalai, padahal ada agenda lain dibalik kebakaran yang terjadi. Modus-modus seperti ini justru dilakukan oleh korporasi besar yang telah bersertifikat ramah lingkungan dan berkelanjutan.

Temuan lain adalah pemanfaatan ilegal kawasan hutan hutan untuk pembangunan kebun sawit. Ada perusahaan yang melaksanakan pembangunan tanaman tanpa izin usaha perkebunan yang sah dan/atau beralas hak (HGU), serta tanpa menggunakan dokumen analisis dampak lingkungan pada daerah dilindungi atau konservasi, bahkan melakukan penimbunan sungai untuk perluasan lahan yang akan dibangun.

\section{Masalah Penegakan Hukum}

Denegakan hukum menjadi masalah 1 tersendiri bagi kasus-kasus pembakaran hutan. Lemahnya koordinasi antar aparat serta rumusan delik dan sanksi kerap gagal memberikan efek jera pada pelaku. Hanya sedikit aparat penegak hukum yang mengerti penanganan masalah penegakan hukum lingkungan, khususnya dalam kasus kebakaran. Kekurangjelasan pemahaman pada pokok persoalan dalam hal ini tentang ilmu mengenai dampak kebakaran hutan dan lahan dan prosesnya, akan menjadi hambatan. Sehingga sering terjadi perbedaan pendapat pada aparat penegak hukum sendiri yang berujung pada pelemahan substansi perkara.

Seperti misalnya untuk penanganan perusahaan perkebunan sawit yang membakar 1.000 hektar lahan dengan kerugian lingkungan hidup Rp 366 miliar, namun vonis pengadilan hanya 3 tahun setara dengan vonis kepada masyarakat yang membakar lahan 1 hektar. Atau pun kasus perusahaan asing yang diduga membakar 3.000 hektar justru hanya didenda Rp 2 miliar, 
padahal kerugian lingkungannya lebih dari Rp 1 triliun. Ini belum termasuk kerugian yang dialami masyarakat akibat kabut asap. Sehingga jelas terlihat lemahnya penegakan hukum pada pelaku pembakaran hutan dan lahan membuat pelaku tidak jera dengan perbuatannya.

Penyelesaian hukum atas praktik pembakaran hutan dan lahan menurut Guru Besar Fakultas Kehutanan Institut Pertanian Bogor, Bambang Hero Saharjo, tidak cukup hanya dengan pidana atau perdata, karena banyak hal yang dapat diungkap dengan menggunakan berbagai aturan terkait atau multidoor. Artinya penyelesaian hukum bisa menggunakan aturan yang terkait seperti aturan kearifan lokal, aturan pengelolaan keanekaragaman hayati, hukumadat setempat dan aturan-aturan lainnya. Tujuannya adalah untuk mengoptimalkan efek jera pada pelaku utama, mengembalikan kekayaan negara dan memulihkan lingkungan hidup.

Ketidakpatuhan

perusahaan untuk memenuhi sarana dan prasarana pengendalian kebakaran juga menjadi fakta tersendiri dalam penegakan hukum. Hal lain yang perlu diperhatikan bahwa kebakaran lahan di area konsesi terkait erat dengan konflik dengan masyarakat, baik di kawasan lindung perusahaan areal pemanfaatan, maupun dibatas lahan masyarakat dan perusahaan. Pemanfaatan Sistem Perangkat Bahaya Kebakaran sebagai bentuk peringatan dini juga masih minim. Aparat yang ada cenderung bergantung pada peran hujan buatan dan bom air yang berbiaya besar. Padahal pencegahan bahaya kebakaran sangat menentukan pengendalian kebakaran. Dari data di BNPB sendiri, dana pemadaman kebakaran lahan di Sumatera dan Kalimantan dialokasikan Rp 350 miliar hingga Agustus 2015, yang semestinya dana tersebut menurut Guru Besar IPB Bambang Hero, dapat dipergunakan untuk kegiatan pencegahan bukan penanggulangan.

\section{Upaya Pemulihan}

Tpaya pemulihan yang dilakukan untuk mengembalikan lahan dan hutan sesuai peruntukannya tidaklah mudah. Karena itu Wahana Lingkungan Hidup (Walhi) Riau melalui direktur eksekutifnya, Riko Kurniawan mendesak pemerintah agar tegas melakukan penataan ulang. Areal gambut yang tersisa di Riau tinggal dua juta hektar, namun masih terancam beralih fungsi karena banyak pihak yang mengklaim kepemilikan lahan di atasnya. Menurut Riko, bukan tidak mungkin mengelola gambut yang tersisa yang kondisinya masih baik. Tanaman endemik akan adaptif jika dikembangkan, seperti meranti rawa, kempas rawa, jelutung, medang dan tembesu. Ketika tanamantanaman tersebut ditanam akan lebih mendukung pemulihan kawasan yang telah rusak dan tidak memerlukan kanal. Cara penghutan kembali juga dilakukan warga, salah satunya yang dilakukan kelompok petani di Desa Teluk Leban, Bukit Batu, Kabupaten Bengkalis. Hasilnya sangat efektif mengendalikan banjir dan kebakaran.

Bencana kabut asap adalah salah satu bencana atas eksploitasi hutan gambut. Bencana-bencana berikutnya tanpa disadari mulai terjadi sebagai akibat pengelolaan hutan yang tidak sesuai peruntukannya. Kerusakan hutan gambut di Kabupaten Hilir misalnya, mengakibatkan intrusi air laut yang menelan daratan hingga jarak dua kilometer sejak tiga tahun terakhir. Tidak ada penahan air yang selama ini dilakukan oleh fungsi hutan, tapi karena ditebangnya pepohonan membuat air laut semakin mengarah pada daratan. Sehingga sejumlah pulau kecil pun dinyatakan telah hilang. 
Hutan merupakan salah satu keanekaragaman hayati yang kita miliki, tanpa pengelolaan hutan yang baik dan berkelanjutan membuat fungsi hutan akan terhenti hanya pada suatu masa saja. Di dalam hutan sendiri pun menyimpan keanekaragaman hayati yang beranekaragam jenisnya. Ada hewan besar seperti orangutan, ular dan monyet berbagai jenis yang bisa saja mereka melarikan diri, terluka, atau bahkan mati. Untuk jenis biota yang tidak bisa menghindar maka mereka tidak bisa bergerak ke mana pun, seperti jenis pohon dan tumbuhan pun akan mati. Untuk kebakaran yang terjadi setiap tahunnya Indonesia kehilangan besar dan tak terhitung dan mungkin tak terpulihkan.

Kebakaran yang ada akan memotong siklus dalam berbagai tingkatan, dari fase telur, spora, remaja, dewasa dari berbagai spesies. Ketika spesies yang ada tersebut meloloskan diri, belum tentu mereka akan kembali karena mereka ini endemik, akan punah karena tidak menemukan habitat yang cocok. Laju hilangnya spesies di kawasan hutan, menurut Program Lingkungan PBB (UNEP), lebih cepat dibanding ekosistem lainnya. Periode 2008-2050, diproyeksikan ada kehilangan 38 persen spesies yang ada di hutan (UNEP-GLOBIO 2008). Selain kebakaran, konversi kawasan hutan ke lahan pertanian dan perkebunan, polusi, perubahan iklim, serta spesies invasif (dari luar ekosistem) yang semuanya berdampak pada pengelolaan kawasan hutan.

Upaya pemulihan hutan ketika ekosistem hancur dengan cara terbakar dan terjadi pada skala luas serta lama, karena pemulihan hutan atau ekosistem akan membutuhkan waktu puluhan tahun. Karena pemulihan ekosistem dibutuhkan proses secara bertahap dan saling ketergantungan, antara hewan berbagai ukuran, besar dan kecil, antara flora dan fauna. Sebagai contoh pembentukan ekosistem baru yang terjadi di Anak Krakatau itu memakan waktu hingga puluhan tahun, seperti pemulihan hutan yang terbakar di Kalimantan pada tahun 1980-an, sampeai sekarang belum pulih sepenuhnya.

\section{KESIMPULAN}

$\mathrm{D}$ ari penelusuran berdasarkan fakta-fakta di atas dapat ditarik kesimpulan bahwa kegiatan manusia dapat berdampak bagi keanekaragaman hayati baik berdampak positif maupun berdampak negatif. Cuma yang diharapkan adalah dampak positif karena upaya untuk pemanfaatan hutan secara berkelanjutan bukan hanya pada satu masa atau satu waktu saja. Karena hutan selain merupakan keanekaragaman hayati juga merupakan potensi lokal (kearifan lokal) yang harus terus menerus dijaga dan dilestarikan untuk keberlangsungan dari hutan itu sendiri. Untuk itu dibutuhkan peran dari semua pihak baik peran pemerintah maupun masyarakat.

\section{DAFTAR PUSTAKA}

Undang-undang Lingkungan Hidup No. 32 tahun 2009 tentang Perlindungan dan Pengelolaan Lingkungan Hidup;

Keputusan Presiden Nomor 32 tahun 1990 tentang Pengelolaan Kawasan Lindung;

Douglas Sheil, Rajindra Puri \& Tim ITTO; Pandangan Masyarakat Lokal Mengenai Berbagai Berbagai Lanskap Hutan; Center for International Forest Research; Jakarta; 2004;

Sunaryati Hartono, Penelitian Hukum di Indonesia Pada Akhir Abad Ke-20, Alumni, Bandung, 1994;

National Geographic Indonesia, edisi Maret 2014;

Harian Kompas, 26 Oktober 2015;

National Geographic, September 2015. 